\title{
Perheammattilaisten asemoituminen VANHEMMUUTEEN JA VANHEMMUUTTA KOSKEVAT KEHYKSET EROTYÖSSÄ
}

Leena Autonen-Vaaraniemi: YTT, yliopistonlehtori, Tampereen yliopisto

leena.autonen-vaaraniemi@tuni.fi

Janus vol. 27 (4) 2019, 362-378

Tiivistelmä

\section{(U) \\ oj a I U S}

VERTAISARVIOITU
KOLLEGALT GRANSKAD
PEER-REVIEWED
www. tsv.fift tunnus

Artikkelissa tarkastellaan eron parissa työskentelevien perheammattilaisten asemoitumista vanhemmuuteen ja vanhemmuutta koskevia kehyksiä. Aineisto koostuu sosiaalityöntekijöiden, psykologien, käräjäoikeuden tuomareiden ja kaupungin lakimiesten haastatteluista. Analyysi pohjautuu kehysanalyysiin ja laadullisen asennetutkimuksen lähestymistapaan. Analyysi osoittaa, että perheammattilaisten suhtautumisessa eron jälkeiseen vanhemmuuteen on jaettuja kehyksïa. Vanhemmuutta jäsennetään lapsen edun selvittämisen, vanhemmuussuhteiden jatkuvuuden sekä arjen ja hoivan kannalta. Keskeistä on erojen tapauskohtaisuuteen ja perheiden elämäntilanteiden kunnioittamiseen perustuva ratkaisujen räätälöinti eron sopimus- ja kiistatilanteisiin. Perheammattilaisten suhtautumisen tavoissa korostuu äitien ja isien yhdenveroisen kohtelun ihanne. Vanhemmuuden sukupuoli peittyy tasaveroista vanhemmuutta painottavaan puhetapaan. Jaetut kehykset ja monipuoliset tiedon lajit tuovat näkyviin erotyötä tekevien perheammattilaisten yhteistyön mahdollistuksia.

\section{JOHDANTO}

Avioerojen yleistyminen ja eroihin liittyvät ongelmat ovat saaneet aikaan tarpeen kehittää palveluita vanhempien ja lasten tukemiseksi erotilanteessa. Erityisesti vanhempien väliset konfliktit, huoli eron vahingollisista vaikutuksista lapsiin ja eri oikeusasteita kuormittavat pitkittyneet huoltoriidat ovat syitä eropalveluiden järjestämiseen ja kehittämiseen (Hämäläinen ym. 2012, 10-11). Eropalveluista on tullut uusi professioiden alue (Baitar ym. 2012, 2013), jossa monet eri ammattilaiset, kuten juristit, perheasiainsovittelijat, mielenterveysalan työntekijät, terapeutit, psykologit ja sosiaalityöntekijät tarjoavat tukea ja neuvontaa eroaville tai eronneille vanhemmille ja perheille (ks. myös Nur- melan \& Kaittilan puheenvuoro tässä numerossa).

Eropalveluita on kritisoitu irrallisiksi ja ammattialojen mukaan sektoroituneiksi, ja myös tuen tarjonta ja saatavuus vaihtelevat eri puolella Suomea (Mattila-Aalto ym. 2012). Näihin epäkohtiin on pyritty vastaamaan lapsi- ja perhepalveluiden muutosohjelmalla (LAPE), joka oli yksi pääministeri Juha Sipilän hallituksen kärkihankkeista. Hankkeen eräänä tavoitteena oli kehittää eropalveluita laaja-alaiseksi ja monipuoliseksi, hallintorajat ylittäväksi palvelukokonaisuudeksi. Eropalveluiden ehkäisevällä ja varhaisella tuella pyritään huoltokiistojen vähentämiseen sekä vanhempien sovinnollisuuden ja vanhemmuuden jatkuvuuden vahvistamiseen. (Lapsi- ja 
perhepalveluiden muutosohjelma, 23.) Lakia lapsen huollosta ja tapaamisoikeudesta ollaan myös muuttamassa $(190 / 2019)$. Eroon liittyen lakiin on kirjattu vuoroasumisen ehdoista sopimisesta, lapsen oikeudesta tavata erityisen läheistä henkilöä, vanhempien velvollisuudesta myötävaikuttaa lapsen tapaamisoikeuden toteutumiseen sekä lapsen ja vanhemman välisen suhteen säilymiseen huollosta ja tapaamisoikeudesta päätettäessä (ks. Koulun puheenvuoro tässä numerossa).

Tässä artikkelissa tutkin eron parissa työskentelevien perheammattilaisten asemoitumista vanhemmuuteen ja perheammattilaisten vanhemmuutta koskevia kehyksiä. Asemoitumisella tarkoitan sitä, miten perheammattilaiset ottavat kantaa ja perustelevat suhtautumistaan vanhemmuuteen. Kehyksellä tarkoitan asemoitumisen ja suhtautumisen tapoja kokoavaa lähestymistapaa.

Aineistona ovat eri ammattiryhmiin kuuluvien asiantuntijoiden haastattelut, joten näkökulma on organisaatioja ammattirajat ylittävä. Tutkimukseni käytännön kontribuutio liittyy palvelujärjestelmän hajanaisuuteen ja eroauttamistyön kehittämiseen. Tarkastelen yhden ammattialan sijasta erotyön eri ammattilaisia ja etsin heille yhteisiä tulkintakehyksiä. Tutkimukseni tuottaa yhteiskuntapoliittisesti ajankohtaista tietoa LAPE:n tavoitteisiin hajanaisen palvelujärjestelmän uudistamiseksi.

\section{Aiempi tutkimus eROTYÖstä JA EROTYÖN AMMATTILAISISTA}

Ammattilaiset katsovat erotyöskentelyssä eroon liittyviä ratkaisuja ja neu- votteluja ensisijaisesti lapsen asemasta käsin ja lapsen parhaaksi. Erossa vanhemmuutta arvioidaan uudelleen (Kääriäinen 2008) ja puolisoiden täytyy orientoitua vanhemmuuteen uudella tavalla (Smart \& Neale 1999, 71-72).

Suomessa on tehty jonkin verran tutkimusta eropalveluista ja eroauttamistyöstä. On esimerkiksi vertailtu kansainvälisesti eroamisen käytäntöjä ja eropalveluja erilaisten perhekulttuurien ja hyvinvointijärjestelmien näkökulmista (Kääriäinen ym. 2012) tai tarkasteltu sitä, millä tavoin eroauttamisen palvelujärjestelmää ja työmenetelmiä voisi kehittää vastaamaan entistä paremmin vanhempien ja lasten tarpeisiin (Mattila-Aalto ym. 2012). Tutkimusten tulokset tuovat esiin erojen haasteet palveluille ja auttamistyölle. Palvelujärjestelmä ei usein tunnista eroavien vanhempien ja lasten elämäntilanteiden moninaisuutta. (Kääriäinen ym. 2009, 13.)

Kansainvälisessä tutkimuksessa erotyötä ja vanhemmuutta on tutkittu sovittelun, terapeuttisten interventioiden ja eroauttamisen ohjelmien näkökulmista. Kvantitatiivisissa tutkimuksissa on tarkasteltu tukitoimien vaikuttavuutta huoltoriidan keskellä elävien vanhempien yhteistyökykyyn ja lasten hyvinvointiin (esim. Pruett ym. 2005; Trinder ym. 2008) sekä sitä, millä tavoin erosovittelulla pystytään vähentämään vanhempien riitaisuutta ja lisäämään yhteistyötä (Hahn ym. 2000).

Eroon liittyvää ammattilaisten työtä on tutkittu myös tarkastelemalla ammatillisia rajoja ja asiakkuuden rajapintoja. Suomessa aihepiiriä on tutkittu lähinnä opinnäytteissä, joissa on tarkasteltu 
esimerkiksi lastensuojelun sosiaalityöntekijöiden kokemuksia lapsen huolto- ja tapaamisriidoista. Tulosten mukaan työntekijät eivät näe huolto- ja tapaamisriita-asioita lastensuojeluun kuuluviksi, vaan ne voidaan siirtää perheneuvolan, lastenvalvojan tai tuomioistuinten tehtäviksi. (Hilli 2018.) Myös kansainväliset tutkimukset (esim. Saini ym. 2012) osoittavat huoltoriitojen haastavuuden ja tarpeen kehittää erotyön moniammatillista yhteistyötä.

Tutkimukset vanhempien toisiinsa tai lapseen kohdistamasta väkivallasta, huoltoriidoista, vieraannuttamisesta tai vainoamisesta ovat valottaneet erotyön vaativuutta ja erovanhemmuuden kääntöpuolta. Kiinnostuksen kohteena ovat olleet esimerkiksi tuomareiden ja sosiaalityöntekijöiden käsitykset perhesuhteissa tapahtuneesta väkivallasta huoltoriidan asiakirjoissa (Hautanen 2010) ja sosiaalityöntekijöiden laatimat olosuhdeselvitykset ja käräjäoikeuden päätökset lasten asumisesta huoltoriidoissa (Forsberg ym. 2018). On myös tarkasteltu sosiaali- ja terveysalan ammattilaisten suhtautumista lapsen vieraannuttamiseen toisesta vanhemmasta eron jälkeen (Häkkänen-Nyholm 2010; Sorokin 2014) ja eron jälkeistä vainoa ja auttamisjärjestelmää uhrien kokemuksina (Nikupeteri 2016).

Ammattilaisten käsityksï vanhemmuudesta erotyössä on tutkittu kuitenkin vähän tai teemaa on tarkasteltu tietyn ammatin kannalta (Astor 2007). On tutkittu esimerkiksi erosovittelijoiden ja asianajajien asenteita jaetusta vanhemmuudesta ja vanhemmuuden sopimuksista (Baitar ym. 2013) ja sosiaalityöntekijän asiantuntijuutta ja työskentelyn jännitteitä vanhemmil- le tarkoitetussa lapsen huolto- ja tapaamissopimuspalvelussa (Antikainen 2007). Bryna Bogoch ja Ruth Halperin-Kaddari (2007) ovat puolestaan survey-tutkimuksessaan tarkastelleet asianajajien, asianajaja-sovittelijoiden ja terapeuttisesti suuntautuneiden sovittelijoiden välistä kilpailua erotyön asiantuntijuudesta ja professioiden rajojen määrittelyistä Israelissa. Tulokset osoittavat, että asianajajien mielestä terapeuttisesti suuntautuneet sovittelijat tunkeutuivat asianajajien osaamisalueelle, kun taas sovittelijat näkivät erotyön uutena ammattialana.

Tutkimukseni näkökulma sijoittuu lähimmäksi Anne Palmusen (2012) tutkimusta, jossa tarkasteltiin asiantuntijoiden käsityksïa eron jälkeisen vanhemmuuden vaikutuksista lapseen eronneita vanhempia käsittelevissä lehtiartikkeleissa vuosilta 1940-2000. Tulosten mukaan 1940-1950-luvulla asiantuntijoiden käsityksissä painottui äitiyden merkitys, kun taas 1990-luvulta lähtien on korostettu sukupuolineutraalisuutta. Samankaltainen muutos ilmenee 1980-luvun lainsäädännössä, jolloin Suomessa siirryttiin sukupuolineutraaleihin lakeihin.

\section{Metodologiset LÄHTÖKOHDAT JA AINEISTO}

Tutkimus lähti liikkeelle kiinnostuksesta vanhemman sukupuolen merkitykseen erojen parissa työskentelevien perheammattilaisten työssä. Kriittisten näkökantojen mukaan erotyön ammattilaiset syrjivät isiä lasten huoltajuudesta, elatuksesta ja asumisesta neuvoteltaessa. Väitettiin, että naisammattilaiset asettuvat erotilanteissa äidin puolelle. 
(Malmi 2009, 321-325; Nathanson \& Young 2006.) Lähdin "testaamaan" tällaisia väitteitä keräämällä aineiston laadullisen asennetutkimuksen metodilla (Vesala \& Rantanen 2007a).

Tutkimukseni paikantuu sosiaalisen konstruktionismin suuntaukseen, jossa korostetaan sosiaalisen todellisuuden rakentumista kielen, käsitteellisten kehysten, kategorioiden ja muunlaisten representaation muotojen kautta, osana kulttuurista ja historiallista kontekstia (Burr 1995; Gergen 1994). Tarkasteluni kohteena on puhe ja siinä rakentuvat merkityssysteemit. Metodologisesti hyödynnän artikkelissani kehysanalyyttista lähestymistapaa (Goffman 1986), jossa tilanteiden tulkinnan nähdään rakentuvan erilaisten kehysten kautta. Kytken tulkintakehyksen idean (Goffman 1986) laadullisen asennetutkimuksen näkökulmaan (Vesala \& Rantanen 2007a). Tämä tarkoittaa ensinnäkin sitä, että keräsin aineiston laadullisen asennetutkimuksen menetelmällä. Analysoin aineiston hyödyntämällä sekä laadullisen asennetutkimuksen että kehysanalyysin periaatteita siten, että kokosin aineistosta löytämiäni asemoitumisen ja suhtautumisen tapoja tulkintakehyksen käsitteen avulla. Lähestymistapaa soveltaen tarkastelen perheammattilaisten asemoitumista vanhemmuuteen erotyössä. Tutkimuskysymyksenä on: millaisten kehysten kautta perheammattilaiset jäsentävät eron jälkeistä vanhemmuutta?

Kutsun eron parissa työskenteleviä ammattilaisia perheammattilaisiksi. Perheammattilaisten työ ylittää instituutioiden rajoja ja organisatorisia jakoja ja sitä tehdään monenlaisissa instituutioissa (Nätkin \& Vuori 2007,
7-9; Vuori 2001, 14). Näkökulmani rajautuu perheammattilaisten työssä vanhemmuuteen. Perhetyö on osa laajempaa perhepolitiikkaa, jolla luodaan lainsäädännöllistä, materiaalista ja keskustelullista tukea perheille. Perhetyö kytkeytyy kulttuurisiin ajattelutapoihin ja ideologioihin, joilla rakennetaan perheideaalia sekä säädellään perheenjäsenten suhteita, oikeuksia ja velvollisuuksia. (Nätkin \&Vuori 2007, 8.) Siksi eron parissa työskentelevien perheammattilaisten näkökulma eron jälkeiseen vanhemmuuteen on olennaista nähdä myös yhteiskunnallisena kysymyksenä.

Analyysi pohjautuu 18 erotyötä tekevän perheammattilaisen haastatteluun. Haastattelut tehtiin vuosina 20112012. Rekrytoin haastateltavat erään suuren kaupungin perheasiain ja käräjäoikeuden yksiköiden kautta. Haastateltavat olivat lastenvalvojia, olosuhdeselvityksï tekeviä sosiaalityöntekijöitä, perheneuvolan sosiaalityöntekijöitä ja psykologeja, käräjäoikeuden tuomareita ja kaupungin lakimiehiä. Heidän työuransa pituus vaihteli viidestä kymmeneen vuoteen. Haastateltavista naisia oli 16 ja miehiä 2. Haastattelujen kesto oli keskimäärin noin 70 minuuttia. Haastattelut tallennettiin ja litteroitiin.

Laadullisen asennetutkimuksen lähestymistapaa hyödyntäen (Vesala \& Rantanen 2007b, 38-43) keräsin aineiston yhdistämällä puolistrukturoituun teemahaastatteluun provokatiivisia väitteitä. Tavoitteena oli saada esiin perheammattilaisten suhtautumistapoja julkisessa keskustelussa kiistanalaiseen kysymykseen isän ja äidin asemasta erossa ja perheammattilaisten erotyössä. Muodostin väitteet yleisönosastokirjoitusten, eronneille miehille suun- 
nattujen oppaiden ja kirjallisuuden sekä miesaktivismiryhmän miehille suunnattujen eroa koskevien internetsivustojen pohjalta. Tähän valitsin analysoitavaksi kahdeksaan väittämään virinneen kommentoinnin, koska ne tuottavat artikkelin tutkimuskysymyksen kannalta relevanttia tietoa (liite 1). Väittämiä oli kaikkiaan 22 kappaletta, mutta useampia väitteitä ja niihin liittyvää kommentointia ei ollut mahdollista analysoida artikkelin rajallisen laajuuden vuoksi.

Analyysin ensimmäisessä vaiheessa sovelsin laadullisen asennetutkimuksen periaatteita. Siinä kiinnostuksen kohteena on, mitä ihmiset arvottavat, kun heitä pyydetään kommentoimaan asioita tai kiistanalaisia ilmiöitä. Asenteet ovat yksilön asemoitumisen tai suhtautumisen tapoja, ja ne koostuvat arvottamisen kohteesta, kannanotoista sekä niihin liittyvistä selonteoista ja perusteluista. (Vesala \& Rantanen 1999, 2007.) Näiden lähtökohtien mukaisesti analysoin haastattelupuhetta kommentointina eritellen aluksi haastateltavien esittämiä kannanottoja ja niiden perusteluja kuhunkin väittämään. Sen jälkeen ryhmittelin kannanottoja ja perusteluja edelleen alaryhmiin erojen ja yhtäläisyyksien mukaisesti. Tulkintani lähtökohtana olivat ne asiayhteydet, joihin haastateltavat vetosivat useiden eri väitteiden yhteydessä. Kannanottojen ja perustelujen yhdistelmistä koostui havaintoluokkia, jotka voidaan tulkita asemoitumisen tavoiksi. Tarkastelin havaintoluokkia siitä näkökulmasta, miten ja millaisena kommenteissa arvotettiin eron jälkeistä vanhemmuutta. Näistä kannanottojen ja perustelujen luokitteluista muodostui merkitysko- konaisuuksia, joita nimitän jatkossa asemoitumisen tai suhtautumisen tavoiksi.

Asemoitumisen tapana kuvattavaa arvottamista voidaan eritellä tarkemmin kehysanalyyttisen lähestymistavan ja tulkintakehyksen idean avulla (Rantanen 2007). Erving Goffmanin (1986) mukaan yksilö tulkitsee sosiaalista todellisuutta erilaisten kehysten kautta. Kehykset ovat vuorovaikutuksessa ja puheessa ilmeneviä määrittelyjä ja jäsennystapoja, joiden avulla tilanteille ja toiminnalle annetaan merkityksiä. Kehykset koostuvat siten merkitysjärjestelmistä. Kehykset ohjaavat toimintaa ja vuorovaikutusta ja ne ovat myös kulttuurisesti rakentuneita. (Peräkylä 1990.) Jäsensin analyysin toisessa vaiheessa erotyötä tekevien perheammattilaisten asemoitumisen ja suhtautumisen tavat edelleen laajemmiksi merkityskokonaisuuksiksi, tulkintakehyksiksi. Kokosin siis kehyksen käsitteellä asemoitumisen ja suhtautumisen tavat. Jatkossa nimitän löytämiäni tulkintakehyksïa kehyksiksi.

Analyysissani keskityin perheammattilaisten jakamiin kehyksiin. Katsoin myös, mitkä kehykset olivat hallitsevia ja mitkä marginaalisia. Kehykset tarkoittavat yhtenäisiä tapoja tulkita ja jäsentää maailmaa. Kehykset eivät kuitenkaan ole yksiselitteisiä ja staattisia, vaan ne voivat olla päällekkäisiä ja vaihtuvia. (Peräkylä 1990.)

Haastateltavat pitkälti väistivät kysymyksen vanhemman sukupuolen merkityksestä. He pitivät ammattitaitona sitä, että suhtautuvat tasapuolisesti asiakkaisiin näiden sukupuolesta riippumatta. Tällainen ilmiö on yleisemminkin havaittu tutkittaessa ammattilaisten asenteita (Vesala \& Rantanen 2007b, 
36-37) ja erotyön asiantuntijoiden käsityksiä (Palmunen 2012, 71-74). Sukupuolineutraalisuuden korostaminen on tullut esiin myös suomalaisessa sosiaalityössä (Kuronen ym. 2004, 5-11). Paikansin aineistostani kolme perheammattilaisten jakamaa, eron jälkeistä vanhemmuutta koskevaa kehystä: vanhempien yhdenveroisen kohtaamisen ihannetta korostavan kehyksen, lapsen edun nimissä yhteistyövanhemmuuden ihannetta esiin tuovan kehyksen sekä arjen vanhemmuutta arvostavan kehyksen.

\section{VANHEMPIEN YHDENVEROISEN KOHTAAMISEN IHANTEEN KEHYS}

Perheammattilaiset jäsensivät suhdettaan vanhemmuuden sukupuolittuneisuuteen neutraalisti; heidän tehtävänään oli kohdata vanhemmat yhdenveroisina sukupuolesta riippumatta. Eri työurat ja koulutustaustat toivat kuitenkin säröjä vanhempien yhdenveroisen kohtaamisen ihanteeseen. Perheammattilaisten asemoitumisen tavoissa tuli esiin myös eron jälkeisen vanhemmuuden moninaisuuden tunnistaminen. Tällaisia asemoitumisen tapoja kokoavaa tulkintakehystä kutsun vanhempien yhdenveroisen kohtaamisen ihanteen kehykseksi, joka oli hallitsevin tunnistamistani tulkintakehyksistä.

Haastatellut korostivat kohtelevansa vanhempia tasapuolisesti ja avoimesti eroon liittyvissä sopimus- ja riitaasioissa. Perheammattilaisten mukaan heidän tehtävänään oli selvittää vanhempien toimimista lasten hoivaajina ja kasvattajina, jolloin vanhempien ei tarvinnut erikseen "todistaa" ammattilaisille kyvykkyyttään toimia isänä tai äitinä lapsen parhaaksi:
Meillä työntekijöillä on vastuu siitä, että osaa kysyä sellaisia kysymyksiä, saada sitä tietoa mitä itse kaipaa, mitä oikeus kaipaa, että ne pystyvät asian ratkaisemaan. (H1, sosiaalityöntekijä)

Jos on hyvä ammattilainen niin hän kyl saa ne tiedot, tai jotenkin pitäs selvittää sitä tilannetta ilman että täytyy kauheesti markkinoida [vanhemmuuttaan] kummankaan. (H10, sosiaalityöntekijä)

Haastatellut perustelivat kannanottojaan sillä, että yleensä erossa ei ole voittajia, vaan ainoastaan häviäjiä. Perheammattilaisten mukaan ero merkitsi eroaville puolisoille ja heidän lapsilleen usein jonkinasteista ydinperheideaalin menetystä. Siksi vanhemmuutta ei tässä yhteydessä tullut nähdä äitien ja isien yhdenvertaisuuteen liittyvänä asiana:

Et jokainen menettää, sekä kumpikin vanhempi että lapset niin ne menettää siinä erossa varmasti jotakin ja joku toinen menettää enemmän, toinen vähemmän mut ei sitä voi ajatella tasaarvokysymyksenä. (H14, sosiaalityöntekijä)

Vanhempien yhdenveroisen kohtaamisen ihanteen kehyksessä asemoitumista eron jälkeiseen vanhemmuuteen perusteltiin erojen tapauskohtaisuudella ja vanhempien elämäntilanteiden moninaisuudella. Perheammattilaiset suhtautuivat vanhemmuuteen perheiden erilaisuutta kunnioittaen:

Ihmiset eroavat niin monella tavalla, siinä on niin monta tapaa kuin perhettäkin. (H4, sosiaalityöntekijä) 
Et siin on monia muitakin asioita mitkä liittyy, että aina ratkasu esimerkiksi kumman luokse lapsi asettuu, niin se ei ole siitä kiinni, että kumpi on ikään ku parempi vanhempi, vaan jos se lähtee siitä että miten juuri tämän lapsen kohdalla ja tämän perheen kohdalla on jotenki viisasta ratkasta, niin siinä on monia muitakin asioita. Että molemmat vanhemmat pysyy lapsen elämässä. (H12, psykologi)

Perheammattilaisten erilaiset työurat ja koulutustaustat vaikuttivat haastateltavien mukaan asiakkaiden kohtaamiseen, mikä rikkoi vanhempien yhdenveroisen kohtaamisen ihannetta. Esimerkiksi erään haastatellun mukaan työntekijä,jolla oli vain vähän työkokemusta, saattoi mennä tunnetasolla liikaa mukaan asiakaan elämäntilanteeseen ja asettua toisen vanhemman puolelle eron kiistatilanteissa:

Et kylhä meilläki sosiaalitoimessa, lastensuojelussa, perheneuvoloissa on niin kuitenki eri työuran vaiheessa ja eri koulutustaustan omaavia ja tietysti äidit voi toisiltaan saada tukea puolensa pitämiseen ehkä paremmin kuin isät toisiltaan. Et kyl se on ihan mahdollista et tämmönen epätasapaino syntyy jossain tilanteessa. (H15, psykologi)

Perheammattilaisten mielestä vanhempien yhdenvertainen kohtaaminen merkitsi empaattista suhtautumista, mutta toisaalta oli tärkeää pitää etäisyyttä heidän elämäntilanteeseensa. Käsitys asiakkaiden yhdenveroisesta kohtaamisesta painottaa työntekijän neutraalisuutta ja järkiperäisyyttä. Tämä ilmiö on tuttu yleisemminkin ihmissuhdeammattilaisten työssä. (Forsberg 2006.)
Vanhempien yhdenveroisen kohtaamisen ihanteen kehyksessä perheammattilaiset jäsensivät eron jälkeistä vanhemmuutta tunnistamalla eroavien puolisoiden ja lasten elämäntilanteiden erilaisuutta. Perheammattilaiset pitivät tärkeänä, että eroon liittyviin sopimusja riita-asioihin tulisi löytää räätälöityjä ratkaisuja ja toimintamalleja. Tämänkaltaisia tuloksia on löydetty myös aiemmista erotyötä ja eropalveluita koskevista tutkimuksista (Kääriäinen ym. 2012).

\section{LAPSEN EDUN JA \\ YHTEISTYÖVANHEMMUUDEN \\ IHANTEEN KEHYS}

Perheammattilaiset perustelivat suhtautumistaan eron jälkeiseen vanhemmuuteen vetoamalla lapsen etuun. Vanhempien yhteistyökyky ja vanhemmuuden jatkuvuus nähtiin lapsen etuna. Yhteistyövanhemmuuden kääntöpuolena tuli jonkin verran esiin väkivalta ja vieraannuttaminen. Tällaisia asemoitumisen tapoja kokoavaa tulkintakehystä kutsun lapsen edun ja yhteistyövanhemmuuden ihanteen kehykseksi.

Perheammattilaisten mukaan heidän työnsä tärkeimpänä tavoitteena oli taata lapselle mahdollisimman hyvä elämä ja arjen jatkuvuus vanhempien eron jälkeen. Lapsen tarpeet ja etu loivat perustan eroon liittyvien sopimus- ja riita-asioiden ratkaisemiselle. Perheammattilaisten tehtäväksi asettui lapsen edun selvittäminen ja heidän työskentelynsä nojasi lapsen tarpeita koskevaan tietoon. Haastateltavat vetosivat lasten elämäntilanteiden yksilöllisyyteen ja erilaisuuteen sekä perheiden moninaisuuteen, joista käsin pyrittiin löytämään 
sopiva ratkaisu eron kiistatilanteisiin. Oli otettava huomioon myös lapsen ikä.

Haastateltujen mielestä lapsen etua arvioitaessa kysymykset vanhempien yhdenvertaisuuden toteutumisesta erossa olivat toissijaisia. Esimerkiksi lapsen tapaamisesta sovittaessa kysymystä siitä, minkä verran lapsi viettää aikaansa äidin ja isän luona, ei voinut ratkaista määrällisen tasapuolisuuden pohjalta:

Ei siin oo kysymys siitä että vanhempien pitäs olla tasa-arvosia, vaan kysymys on siitä että lapsen tulevaisuus, et lapsen elämä jatkuu mahdollisimman hyvin niin kuin se eron jälkeen on mahdollista. (H14, sosiaalityöntekijä)

Ei se tarkota, että toinen on huono vanhempi, jos lähivanhemmuus suositellaan toiselle. Kun nyt kiistellään ja vanhemmat ei itse pääse sopimukseen näistä asioista, mikä on tietenkin kauheen surullista että vanhemmat ei ite päätä omien lastensa asioista, vaan sit siihen kysytään ulkopuolisten näkemystä ja tuomari sen päättää. Joku ratkasu täytyy tehä, eikä se tee siitä toisesta vanhemmasta huonompaa. (H18, sosiaalityöntekijä)

Perheammattilaiset suhtautuivat eron jälkeiseen vanhemmuuteen yhteistyövanhemmuuden ihanteen kautta. Haastatellut perustelivat, että vanhempien tulisi tehdä yhteistyötä, tukea toistensa vanhemmuutta ja lapsen suhdetta muualla asuvaan vanhempaan. Ammattilaisten tehtäväksi asettui vanhemmuuden jatkuvuuden tukeminen. Toisaalta perheammattilaiset siirsivät vastuuta eroratkaisuista vanhemmille, jotka ideaalitilanteessa pystyivät itse löytämään parhaiten ratkaisuja sopimus- ja kiistatilanteisiin, jolloin ammattilaisten rooli voi jäädä vähemmälle.

Sehän on niin, että sen jälkeen pitäs alkaa tavallaan vanhemmuus, että lapsi tarvitsee molempia vanhempiaan myös eron jälkeen. Et pulmahan on sit se, että miten se vanhemmuus miten sitä sitten hoidetaan yhteistyössä vaikka ei asuta saman katon alla. (H12, psykologi)

Näissä lapsiriidoissa usein tulee semmonen voimattomuuden tunne että ei tässä pysty tekeen sille lapselle hyvää ratkasua, koska ei pystytä pakottaan niitä vanhempia sopiin. Taikka ei pystytä pakottaan niitä vanhempia johonki tiettyyn muottiin, eikä pystytä pakottaan ketään velvottaan meneen mihinkään hoitoon, eikä työstää sitä avioeroasiaa sinänsä. Että jos ei vanhemmat sitä ite nää niin sille ei sitte oikeen ammattilaisetkaan pysty mitään tekeen. (H9, lakimies)

Lapsen edun ja yhteistyövanhemmuuden ihanteen kehyksessä vanhemmat parhaimmillaan sopivat arjen käytännöistä joustavasti keskenään ja tarvittaessa muuttivat käytäntöjä lapsen tarpeiden mukaisesti. Joidenkin haastateltujen mielestä vanhempien yhteistyö eron jälkeen saattoi tehdä perheestä toimivamman kuin ennen eroa:

Kyllähän sitä on paljon ihan konkreettisesti jaettua vanhemmuutta. Se voi välillä parantaakin sitä perhettä ja siitä voi parhaimmillaan tulla toimivampi. (H10, sosiaalityöntekijä)

Lapsen edun ja yhteistyövanhemmuuden ihanteen kehystä koskevat tutkimustulokseni ovat vastaavanlaisia kuin 
Hannele Forsbergin ja kumppaneiden (2018, 23-31) tutkimuksessa, jossa sosiaalityöntekijöiden laatimien olosuhdeselvitysten yhteenvedoissa ja käräjäoikeuden tuomareiden argumenteissa korostui vanhempien sujuvan yhteistyön ja riidattomuuden merkitys lapsen etuna.

Yhteistyövanhemmuus ja yhteishuoltajuus ovat olleet vuosikymmenten ajan suomalaisen lainsäädännön ja ammatillisten käytäntöjen normeja (Hakovirta \& Rantalaiho 2009). Erojen yleistyttyä avioeroa on alettu pitää normaalina ja myös vanhemmuuden ajatellaan jatkuvan eron jälkeen. Oletetaan, että eronneet puolisot kykenevät yhteistyökykyiseen ja riidattomaan vanhemmuuteen. (Kurki-Suonio 1999, 440-482; myös Castrén ym. tässä numerossa.)

Lapsen edun ja yhteistyövanhemmuuden ihanteen kehyksessä tuli jonkin verran näkyviin vanhempien yhteistyökyvyn kääntöpuoli. Perheammattilaisten argumentoimana yhteistyövanhemmuuden ihannetta kyseenalaistivat vanhempien välinen väkivalta ja lapsen vieraannuttaminen toisesta vanhemmasta. Perheammattilaisten mielestä näiden ilmiöiden selvittäminen oli heidän työssään haasteellista:

Kyllähän semmoset tilanteet missä syytetään väkivallasta toista, ja sit toinen sanoo et ku emmä oo koskaan suhun koskenu, niin siinä aina miettii sitte. Ja sit yrittää niitä tapaamisia turvata et onko paikkaa missä voi tavata et on muita ihmisiä läsnä tai, et tavallaan taas konkreettisesti näyttää omalla käytöksellään että toi toinen ei nyt, tai puheet ei pidä paikkaansa. Tai sit jos puhutaan seksuaalisen hyväksikäytön epäilystäni, enhän mä tässä voi kahen tunnin aikana, toinen sanoo että sä oot nyt tehny jotain tolle lapselle, toinen sanoo et en todellakaan ole, niin eihän mul oo mitään keinoja siinä sanoo että, nyt et saa tavata lasta tai saat. Muuta ku todeta et tää on epäselvä tilanne, et se jonka luona lapsi asuu niin hänen täytyy se ratkasu nyt tehä. Ja sit ohjata heitä eteenpäin, esimerkiks käsittelemään perheneuvolaan sitä, tai pyytää lastensuojelua avuksi. (H6, perheneuvolan sosiaalityöntekijä)

Se vieraantuminen on oma ongelmansa joka tulee sitte aikaa myöten. Miten sitä enää luodaan sitä suhdetta sitten kun sillä lapsella on vähän omaakin ajattelukykyä ja, kuinka paljon lapselle sitten, miten se vaikuttaa semmonen esimerkiks manipulointi lapsen ajattelukykyyn ni, sitäkin voi miettiä että jos lapsi manipuloidaan tarpeeksi syvälle niin, voiko se ajattelutapa sitte sieltä oikeesti ikinä muuttua. Se on aika laiha lohtu sanoa vanhemmalle tällaisessa tilanteessa että no, odotetaan että kun aika tässä kuluu niin kyllä se lapsi siitä tokeentuu että kyllä nää asiat sitte menee eteenpäin. Ainoa mitä tietysti voi pyrkiä siinä tekemään on sitte, sille lähihuoltajalle painottamaan sitä että miten vahingollista sille lapselle on, pitkällä tähtäyksellä se että hänellä ei oo hyvää suhdetta siihen toiseen vanhempaan. Mutta jos se kieltäydytään sitte hyväksymästä et näin olis, niin sillon sekään ei auta. Joskus ollaan vähän umpikujatilanteissa. ( $\mathrm{H} 8$, käräjäoikeuden tuomari)

Edellä olevissa aineistositaateissa perheammattilaiset lähinnä nostivat kädet ylös ja totesivat, ettei heillä ollut keinoja ottaa kantaa mahdolliseen väkival- 
taan tai vieraannuttamiseen. Vanhempia ohjattiin myös muihin palveluihin.

Vaikka haastatellut enimmäkseen väistivät kysymyksen vanhemman sukupuolen merkityksestä, väkivallan ja vieraannuttamisen teemassa sukupuoli oli piiloisesti läsnä. Haastateltujen puhe vanhemmasta, jonka luona lapsi asuu ja vanhemmasta, jota lapsi tapaa, sisältävät oletuksen vanhemmuuden sukupuolesta. Tilastotietojen mukaan suurin osa lapsista jää asumaan äidin luokse eron jälkeen (Lapsen huolto ja elatus sekä isyyden selvittäminen 2018). Tanja Mäkynen (2018,37-49) on tarkastellut pro gradu -tutkielmassaan eron jälkeisen vanhemmuuden yhteiskunnallisia diskursseja sukupuolen näkökulmasta. Yhteiskunnallisissa puhetavoissa sukupuolten eriarvoisuus ilmenee siten, että lapsen vieraannuttaminen yhdistetään miehen naista heikompaan asemaan erossa, väkivaltaa taas ei liitetä äitiyteen. Väkivaltatutkimuksessa sukupuolistunut väkivalta liitetään yleensä naisten alisteiseen yhteiskunnalliseen asemaan (Husso 2003). Vieraannuttamista tarkasteltaessa sukupuolten eriarvoisuus käännetään siis toisin päin. Ero näyttäisi tuottavan väkivaltaa, vieraannuttamista ja sukupuolten eriarvoisuutta koskevaan yhteiskunnalliseen keskusteluun oman sävynsä.

Lapsen etu on keskeinen perheammattilaisten erotyötä määrittävä periaate (Taskinen 2001), jota ohjaa lainsäädäntö (Laki lapsen huollosta ja tapaamisoikeudesta annetun lain muuttamisesta 190/2019). Vanhemmuuden jatkuvuus ja vanhempien kyky riidattomaan yhteistyöhön eron jälkeen nähdään lapsen edun kannalta tärkeänä (Trinder ym. 2008). Lapsen edun periaate on kui- tenkin moniselitteinen ja sen selvittäminen voi olla vaikeaa eron kaltaisessa perheen muuttuvassa elämäntilanteessa (Smithson ym. 2015, 620-621). On mielenkiintoista, jos lapsen etuna nähdään yksioikoisesti vain se, että vanhemmat ovat yhteistyössä. Lapsen etu voisi olla myös esimerkiksi riidaton ja väkivallaton elämä yhden vanhemman kanssa. Varsinkin pitkittyneet, useita vuosia eri oikeusasteissa kestävät huoltoriidat vaikeuttavat vanhemmuussuhteen vaikutusten arviointia (Nielsen 2017). Perheammattilaisilla voi olla myös keskenään eriäviä näkemyksiä vanhemmuuden jatkuvuuden ja lapsen edun yhteydestä (Baitar ym. 2013).

\section{Arjen vanhemmuUden KOKEMUSASIANTUNTIJUUDEN KEHYS}

Perheammattilaiset jäsensivät eron jälkeistä vanhemmuutta arjen vanhemmuuden kokemusten kautta. Kyse oli sekä asiakkaiden ammattilaisille kertomista kokemuksista että perheammattilaisten omista kokemuksista. Ammattilaisten suhtautumisen tavat kiinnittyivät perheen arjen työnjakoon sekä vanhemman ja lapsen väliseen hoivasuhteeseen. Tällaisia asemoitumisen tapoja kokoavaa tulkintakehystä kutsun vanhemmuuden kokemusasiantuntijuuden kehykseksi, joka oli marginaalisin tunnistamistani tulkintakehyksistä.

Perheammattilaiset suhtautuivat eron jälkeiseen vanhemmuuteen vedoten siihen, miten lapsen hoitaminen ja perheen arki oli jaettu vanhempien kesken ennen eroa:

Tapaukses jossa se äiti on konkreettisesti avioliitonkin aikana ollut sen arjen pyö- 
rittäjä, niin mä luulen että niissä tapauksissa varmaan useimmissa se ratkaisu on nimenomaan sellanen, että ne lapset sitte jatkossakin jää äidin luo, ja isä siihen suostuu. Sellaisissa perheissä joissa molemmat on avioliiton aikanakin ollu konkreettisesti mukana siinä arjen pyörityksessä, hoitanu tasavertosesti lapsia niin niissä tapauksissa isät varmaan esittää vaatimuksia ja sillon mä luulen että kysymys siitä arjen pyörittämisestä ei tuu mitenkään konkreettisesti siinä jutun ratkaisussakaan esille. (H8, käräjäoikeuden tuomari)

Sitten on taas se, minkälaisessa parisuhteessa on elänyt. Jos on elänyt siinä perinteisessä kuviossa, että äiti hoitaa lapsia kotona, ja isä käy töissä, niin naiset esittää sitä tässä, että kun minä olen aina lapset hoitanut. Mutta me tuodaan taas esille että eron jälkeen tilanne avautuu tavallaan uudestaan ja silloin molemmat vanhemmat joutuu sitä arkea pyörittämään ja saa pyörittää. (H5, sosiaalityöntekijä)

Ammattilaiset tekivät työtään sen pohjalta, miten he tulkitsivat vanhempien kokemuksen riittävyyttä lasten hoivaajina ja kasvattajina. Vanhempien yhdenveroisen kohtaamisen ihanteen kehyksessä puolestaan ilmeni, ettei vanhempien tarvinnut osoittaa ammattilaisille kyvykkyyttään toimia isänä tai äitinä lapsen parhaaksi. Nämä kaksi asiaa ovat ristiriidassa: yhtälı̈tä perheammattilaiset eivät katsoneet tarvitsevansa tietoa vanhemman kyvykkyydestä toimia isänä tai äitinä, toisaalta tieto vanhempien kokeneisuudesta lasten hoivaajana ja kasvattajana oli tärkeää. Ilmiöiden voi nähdä liittyvän toisiinsa, jolloin vanhemmuuskokemukset kartuttaisivat vanhemmuuden taitoja ja kykyjä.
Haastateltujen mielestä vanhemmilla oli ensisijaista kokemustietoa arjen vanhemmuudesta: vanhemmat tiesivät itse parhaiten, millaiset lasta koskevat ratkaisut erossa olivat heidän lapsilleen parhaaksi. Myös vanhemmuuden kyvykkyyden pohtiminen nähtiin vanhempien asiana:

Kun me ei tehdä päätöksiä, vanhemmat päättää sen. Se on prosessi, jossa he itse arvioivat sitä omaa kyvykkyyttänsä ja me myös autetaan siinä mitä se arki tarkottaa ja mitä se on tavallaan keskustelemaan siitä. Sitten he yhdessä miettii että mikä se on lasten kannalta sitten. (H4, sosiaalityöntekijä)

Tässä kehyksessä perheammattilaiset asemoituivat eron jälkeiseen vanhemmuuteen omasta perhetaustastaan ja elämänhistoriastaan käsin. Haastatellut vetosivat siihen, että omat kokemukset arjen vanhemmuudesta voivat auttaa ymmärtämään asiakkaina olevien vanhempien asemaa ja kokemuksia erossa. Vanhemmuuskokemukset ylittivät ammattilaisen ja asiakkaan välistä rajaa:

Kysymyshän on siitä että mikä sillä ihmisellä sukupuolesta riippumatta on se oma kokemus siitä, et kumpi niistä lapsista huolehtii. Ja meidän perheessä nyt ehkä on sillä tavalla et se ois sitten ollu se isä. Että olen ehkä analyyttisempi tän ammatinkin takia ja hän sitten ei, että se saattaa heijastua sillä tavalla, et esimerkiksi minä otan huomioon ihan yhtälailla isän täysin potentiaalisena lähihuoltajana. (H17, käräjäoikeuden tuomari)

Kyllähän omat kokemukset meitä muovaa, mut ammatillisuus on kuitenki sitä että pääsee yli niistä, ei oo vaan niitten 
omien kokemusten vanki. Ei se että minä oon tässä nainen tai muuta. En voi mitenkään esimerkiksi ajatella että mä pojan äitinä mitenkään suhtautuisin miehiin, oman poikani sukupuoleen, esimerkiksi niin että mä mitätöisin sitä että se on jotenkin kyvyttömämpi joihinkin asioihin kun tytär. (H18, sosiaalityöntekijä)

Tulosteni mukaan sekä vanhempien että ammattilaisten kokemusasiantuntijuus vanhemmuudesta on merkityksellistä perheammattilaisten suhtautumisessa eron jälkeiseen vanhemmuuteen. Myös muut ihmissuhdetyötä tarkastelevat tutkimukset (esim. Forsberg 1998; Sjølie ym. 2013) osoittavat, että ammattilaiset ja vanhemmat tuovat mukanaan asiakastyöhön oman kulttuurisen tietonsa, käsityksensä ja kokemuksensa perheestä. Voi kuitenkin pohtia, kuinka paljon ammattilaisten omat kokemukset saisivat vaikuttaa asiakkaiden elämäntilanteiden jäsentämisessä. Erosovittelijan työtä tutkinut Hilary Astor (2007, 230-236) väittää, ettei ammattilaisen neutraalisuus ole mahdollista. Ammattilaisen tulisi kuitenkin tunnistaa ja ymmärtää oman perhetaustansa, arvojensa, persoonallisuutensa, kulttuurinsa ja ammatillisen historiansa vaikutus työssään.

Perheen arki ja vanhemman hoivasuhde lapseen on erotyötä koskevien tutkimusten mukaan keskeinen perusta arvioitaessa lapsen etua erossa (Smithson ym. 2015, 620). Eron sopimuskäytäntöä koskevassa laissa pyritään vahvistamaan vanhemmuuden sopimuksellisuutta ja siinä otetaan huomioon arjen tilanteet (Laki lapsen huollosta ja tapaamisoikeudesta annetun lain muuttamisesta 190/2019). Arjen tilanteiden merkitys tulee esiin myös eroa koskevissa vanhemmuussopimuksissa. Esimerkiksi lapsi- ja perhepalveluiden muutosohjelmassa on kehitetty eron jälkeisen vanhemmuuden tueksi vanhemmuussuunnitelma, jonka avulla vanhemmat voivat sopia ja keskustella lasten arjen järjestämisestä eron jälkeen. Vanhemmuussuunnitelman lomake rakentuu varsin yksityiskohtaisista kuvauksista arjen hoivavastuusta, käytännöistä ja niistä sopimisesta. (STM: Lapsen arki eron jälkeen - suunnitelma vanhempien yhteistyöstä 2018.)

Perheammattilaisten vetoamisen tavoissa nojataan perinteiseen työnjakoon perheessä ennen eroa, minkä johdosta vanhemmuuden sukupuoliasetelma jatkuu eron jälkeen: kun äiti on hoitanut lasta ennen eroa, niin hän hoitaa lasta sen jälkeenkin. Toisaalta perheammattilaisten suhtautumisessa tunnistetaan myös hoivaava ja osallistuva isyys. Perheammattilaiset kuitenkin korostavat, ettei sukupuolella ole merkitystä arjen vanhemmuutta arvioitaessa. Marjo Kuronen $(2003,107)$ on kuitenkin kritisoinut sitä, että vanhemmuuden sukupuolittuneisuuden häivyttävä puhe piilottaa sukupuolen mukaisen työn, vallan ja vastuun jakamisen perheen arjessa.

\section{JOHTOPÄÄTÖKSET JA POHDINTA}

Eron parissa työskentelevät perheammattilaiset asemoituvat eron jälkeiseen vanhemmuuteen äitien ja isien yhdenveroista kohtelua korostaen. Vanhemmuutta jäsennetään lapsen edun selvittämisen, vanhemmuussuhteiden jatkuvuuden sekä arjen sujumisen ja lapsen hoivan kannalta. Argumentoin- 
nin tavoissa nousee esiin erojen tapauskohtaisuuteen ja perheiden elämäntilanteiden kunnioittamiseen perustuva ratkaisujen räätälöinti sopimus- ja kiistatilanteissa. Perheammattilaisten suhtautumisessa eron jälkeiseen vanhemmuuteen on jaettuja kehyksiä. Tämä avaa uuden näkökulman erotyön ammattilaisia käsittelevään tutkimukseen (esim. Baitar ym. 2013; Bogoch \& Halperin-Kaddari 2007), jossa on tarkasteltu ammattiryhmien välisiä jännitteitä, ammatillisten rajojen puolustamista tai eroja vanhemmuuteen suhtautumisessa. Tutkittaessa esimerkiksi asianajajien ja sovittelijoiden tekemää erotyötä näkökulmana on ollut kilpailu erotyön asiantuntijuudesta (Bogoch \& Halperin-Kaddari 2007). Tutkimukseni tulokset tuovat sen sijaan esiin eri perheammattilaisten yhteisesti jakamaa ymmärrystä eron jälkeisestä vanhemmuudesta ja ammattirajoja ylittäviä kosketuspintoja.

Ammatillisten rajojen ylläpitämisellä on seurauksia. Esimerkiksi lastensuojelun ja huoltoriitojen yhdyspintoja tarkasteleva tutkimus on osoittanut, että huoltoriitojen rajaaminen lastensuojelun ulkopuolelle voi aiheuttaa rajapinta-asiakkuutta ja asiakkaiden siirtämistä palvelusta toiseen. Äärimmillään kukaan ei ota vastuuta lapsen tilanteesta ja eroperheen ongelmista (Hilli 2018; Saini ym. 2012), millä voi olla vakavia seurauksia. Analyysissa tuli esiin myös väkivalta ja vieraannuttaminen ilmiöinä, joita perheammattilaiset joutuvat kohtaamaan, mutta joiden suhteen heillä ei ollut paljon keinoja. Eropalveluissa olisikin syytä panostaa vanhempien väkivallan $\mathrm{ja}$ vieraannuttamisen tunnistamiseen ja varhaisen vaiheen eropalvelujen järjestämiseen. Sovittelu- palveluja tulisi olla tarjolla myös siinä vaiheessa, kun erokonflikti on jo päässyt syvenemään. (Mattila-Aalto ym. 2012, 236-238; Tapola-Haapala ym. 2012, 116-117.)

Tulosten perusteella perheammattilaisten asemoitumisen tavat, jotka perustuvat arjen työnjakoon, vanhemman ja lapsen väliseen hoivasuhteeseen ennen eroa sekä tasa-arvoisen vanhemmuuden korostamiseen, voivat tuottaa vanhemmuuden sukupuolittuneisuutta, joka toisaalta halutaan häivyttää. Tarvitaan sukupuolen merkitysten tunnistamista erotyön käytännöissä ja sukupuolisensitiivistä tutkimusta aihepiiristä (Kuronen 2003).

Lait ja ohjeet eivät tarjoa valmiita ratkaisuja erotyön monimutkaisiin ja kiistanalaisiin tilanteisiin. Koulutuksen ja tieteellisen erityistiedon lisäksi tarvitaan arkikokemuksiin perustuvia tietoja ja taitoja sekä tunnetietoa, jotka hyväksytään osaksi perheammattilaisten asiantuntijuutta. (Forsberg 2006; Sjølie ym. 2013.) Erotyön ammattilaisten työskentely näyttäisi kutsuvan moraalista järkeilyä, jossa ristiriitaista ja epävarmaa tietoa sisältävien asiakkaiden ongelmatilanteiden ratkaiseminen edellyttāä monipuolisia tiedon lajeja (Forsberg 2012, 16-17).

Aineistosta paikantamani kehykset ovat osittain limittäisiä ja päällekkäisiä. $\mathrm{Ne}$ ovat myös ajallisia ja paikallisia, kulttuurisesti rakentuneita. Äitien ja isien yhdenveroista kohtaamista, eron jälkeistä yhteistyövanhemmuutta ja lapsen etua koskevat kehykset ilmentävät osaltaan vanhemmuutta ja lasta koskevia yhteiskunnallisia diskursseja (AutonenVaaraniemi 2010). Tulokseni vahvista- 
vat tulkintaa siitä, että erotyö kietoutuu osaksi perheideaalia rakentavia kulttuurisia ajattelutapoja ja ideologioita (Nätkin \& Vuori 2007, 8). Ideologioiden haastamiseksi olisi tärkeää, että perheammattilaiset tunnistaisivat niitä työssään (Autonen-Vaaraniemi 2012).

Tulokseni tukevat näkemyksiä, joiden mukaan eropalvelujen kehittämiseksi tulisi ammatillisten rajojen ylläpitämisen sijasta suuntautua moniammatilliseen, organisaatiorajat ylittävään erotyöhön (Mattila-Aalto ym. 2012; Saini ym. 2012). Analyysini esiin tuomat, erotyön ammattilaisten jakamat kehykset näyttäisivät vahvistavan hyvin LAPE-ohjelman tavoitteita pirstaleisen palvelujärjestelmän ja auttamistyön uudistamiseksi.

Jatkossa tarvitaan lisää empiiristä tutkimusta erotyön ammattilaisista, moniammatillisesta yhteistyöstä ja vanhemmuuden määrittelyistä erotyössä. Tutkimustulokseni tuovat näkyväksi erojen parissa työskentelevien perheammattilaisten yhteistyön mahdollistuksia jaettuina kehyksinä ja monipuolisina tiedon lajeina.

\section{KirjallisuUs}

Autonen-Vaaraniemi, Leena (2010) Men's activism, moral reasoning and good fatherhood in post-divorce family context. NORMA - Nordic Journal for Masculinity Studies 5 (1), 45-59.

Autonen-Vaaraniemi, Leena (2012) Eroisyyden oikeuttamisen periaatteet. Teoksessa Hannele Forsberg \& Leena AutonenVaaraniemi (toim.) Kiistanalainen perhe, moraalinen järkeily ja sosiaalityö. Tampere: Vastapaino, 101-122.

Antikainen, Mari (2007) Sosiaalityöntekijän asiantuntijuus lapsen huolto- ja tapaamis- sopimuspalvelussa. Kuopion yliopiston julkaisuja E. Yhteiskuntatieteet 148. Kuopio: Kuopion yliopisto.

Astor, Hilary (2007) Mediator neutrality: Making sense of theory and practice. Social \& Legal Studies 16 (2), 221-239. https:// doi.org/10.1177/0964663907076531

Baitar, Rachid \& Buysse, Ann \& Brondeel, Ruben \& de Mol, Jan \& Rober, Peter (2012) Post-divorce wellbeing in Flanders: Facilitative professionals and quality of arrangements matter. Journal of Family Studies 18 (1), 62-75. https://doi. org/10.5172/jfs.2012.18.1.62

Baitar, Rachid \& Buysse, Ann \& Brondeel, Ruben \& de Mol, Jan \& Rober, Peter (2013) Divorce professionals in Flanders: policy and practice examined. Family Court Review 51 (4), 542-566. https:// doi.org/10.1111/fcre.12051

Bogoch, Bryna \& Halperin-Kaddari, Ruth (2007) Co-optation, competition and resistance:mediation and divorce professionals in Israel. International Journal of the Legal Profession 14 (2), 115-145. https:// doi.org/10.1080/09695950701616481

Burr, Vivien (1995) An introduction to social constructionism. London: Routledge. https://doi.org/10.4324/9780203299968

Forsberg, Hannele (1998) Perheen ja lapsen tähden. Etnografia kahdesta lastensuojelun asiantuntijuudesta. Helsinki: Lastensuojelun keskusliitto.

Forsberg, Hannele (2006) Tunteet työssä - esimerkkinä sosiaalityönä tehtävä ihmissuhdetyö. Teoksessa Kaarina Määttä (toim.) Tunteiden rakkaus ja rikkaus. Avaimia tunteiden tulkintaan. Helsinki: Finn Lectura, 27-44.

Forsberg, Hannele (2012) Johdatus kirjan käsitemaailmaan. Teoksessa Hannele Forsberg \& Leena Autonen-Vaaraniemi (toim.) Kiistanalainen perhe, moraalinen järkeily ja sosiaalityö. Tampere:Vastapaino, 7-21.

Forsberg, Hannele \& Kääriäinen, Aino \& Ritala-Koskinen, Aino (2018) Children's residence in divorce disputes - Examination of social workers' court reports. Journal of Social Welfare and Family Law 39 (1), 21-36. https://doi.org/10.1080/0964 9069.2018.1414351

Gergen, Kenneth J. (1994) Realities and relationships. Soundings in social con- 
struction. Cambridge: Harvard University Press.

Goffman, Erving (1986[1974]) Frame analysis. An essay on the organization of experience. Boston: Northeastern University Press.

Hahn, Robert A. \& Kleist, David M. (2000) Divorce mediation: Research and implications for families and couples counseling. The Family Journal 8 (2),165-171.https:// doi.org/10.1177/1066480700082009

Hakovirta, Mia \& Rantalaiho, Minna (2009) Perhepolitiikka ja jaettu vanhemmuus. Teoksessa Aino Kääriäinen, Juha Hämäläinen \& Pirjo Pölkki (toim.) Ero, vanhemmuus ja tukeminen. Helsinki: Lastensuojelun Keskusliitto, 36-60.

Hautanen, Teija (2010) Väkivalta ja huoltoriidat. Acta Universitatis Tamperensis 1544. Tampere:Tampere University Press.

Hilli, Ulla (2018) Huoltoriidat lastensuojelutarpeen arviointiprosessissa: sosiaalityöntekijän näkökulma. Sosiaalityön pro gradu -tutkielma. Tampereen yliopisto, yhteiskuntatieteiden tiedekunta.

Husso, Marita (2003) Parisuhdeväkivalta: lyötyjen aika ja tila.Tampere:Vastapaino.

Häkkänen-Nyholm, Helinä (2010) Lapsen vieraannuttaminen toisesta vanhemmasta erotilanteessa. Duodecim 126 (5), 499505.

Hämäläinen, Juha \& Kääriäinen, Aino \& Pölkki, Pirjo (2012) Varieties of divorce - unique personal experiences in diverse society orders, welfare systems and family cultures. Teoksessa Aino Kääriäinen, Juha Hämäläinen \& Pirjo Pölkki (toim.) Challenges of divorce, interventions and children. Eron haasteet, väliintulot ja lapset. Helsinki: Ensi- ja turvakotien liitto, 8-13.

Kurki-Suonio, Kirsti (1999) Äidin hoivasta yhteishuoltoon - lapsen edun muuttuvat oikeudelliset tulkinnat. Helsinki: Suomalainen lakimiesyhdistys.

Kuronen, Marjo (2003) Eronnut perhe? Teoksessa Hannele Forsberg \& Ritva Nätkin (toim.) Perhe murroksessa. Kriittisen perhetutkimuksen jäljillä. Helsinki: Gaudeamus, 103-120.

Kuronen, Marjo \& Granfelt, Riitta \& Nyqvist, Leo \& Petrelius, Päivi (2004) Sukupuolistunut ja sukupuoleton sosiaalityö. Teoksessa Marjo Kuronen, Riitta Gran- felt, Leo Nyqvist \& Päivi Petrelius (toim.) Sukupuoli ja sosiaalityö. Jyväskylä: PSkustannus, 5-18.

Kääriäinen, Aino (2008) Ero haastaa vanhemmuuden. Helsinki: Lastensuojelun Keskusliitto.

Kääriäinen, Aino \& Hämäläinen, Juha \& Pölkki, Pirjo (2009) Ero, vanhemmuus eron jälkeen ja eroauttaminen tutkimuskohteina. Teoksessa Aino Kääriäinen, Juha Hämäläinen \& Pirjo Pölkki (toim.) Ero, vanhemmuus ja tukeminen. Helsinki: Lastensuojelun Keskusliitto. 11-16.

Kääriäinen, Aino \& Hämäläinen, Juha \& Pölkki, Pirjo (toim.) (2012) Challenges of divorce, interventions and children. Eron haasteet, väliintulot ja lapset. Helsinki: Ensi- ja turvakotien liitto.

Laki lapsen huollosta ja tapaamisoikeudesta annetun lain muuttamisesta 190/2019.

Lapsen huolto ja elatus sekä isyyden selvittäminen 2018. Tilastoraportti 11/2019. Suomen virallinen tilasto http://www.julkari.fi/bitstream/handle/10024/138097/ tr11_19.pdf?sequence $=1$ \&isAllowed $=y$ Luettu 20.6.2019.

Lapsi- ja perhepalveluiden muutosohjelma https://stm.fi/hankkeet/lapsi-ja-perhepalvelut Luettu 20.6.2019.

Malmi, Pasi (2009) Discrimination against men: Appearance and causes in the context of a modern welfare state. Acta Universitatis Lapponiensis 157. Rovaniemi: Lapin yliopisto.

Mattila-Aalto, Minna \& Bergman-Pyykkönen, Marina \& Haavisto, Vaula \& Karvinen-Niinikoski, Synnöve (2012) Konfliktiteoreettinen näkökulma eroihin ja palvelujen kehittämiseen, Teoksessa Aino Kääriäinen, Juha Hämäläinen \& Pirjo Pölkki (toim.) Challenges of divorce, interventions and children. Eron haasteet, väliintulot ja lapset. Helsinki: Ensi- ja turvakotien liitto, 213-241.

Mäkynen, Tanja (2018) Lapsen vieraannuttaminen julkisessa keskustelussa. Diskurssianalyyttinen tutkimus. Pro gradu -tutkielma. Jyväskylän yliopisto, humanistis-yhteiskuntatieteellinen tiedekunta.

Nathanson, Paul \& Young, Katherine K. (2006) Legalizing misandry: From public shame to systemic discrimination against men. Montreal: McGill-Queen's University Press. 
Nielsen, Linda (2017) Re-examining the research on parental conflict, coparenting, and custody arrangements. Psychology, Public Policy and Law 23 (2), 211-231. https://doi.org/10.1037/law0000109

Nikupeteri, Anna (2016) Vainottuna: eron jälkeisen vainon tunnistaminen ja uhrien kohtaaminen. Acta Universistatis Lapponiensis 336. Rovaniemi: Lapin yliopisto.

Nätkin, Ritva \& Vuori, Jaana (2007) Perhetyön tieto ja kritiikki. Johdanto perhetyön muuttuvaan kenttään. Teoksessa Jaana Vuori \& Ritva Nätkin (toim.) Perhetyön tieto. Tampere:Vastapaino, 7-38.

Palmunen, Anne (2012) Asiantuntijoiden käsitykset yksivanhempaisuudesta. Teoksessa Aino Kääriäinen, Juha Hämäläinen \& Pirjo Pölkki (toim.) Ero, vanhemmuus ja tukeminen. Helsinki: Lastensuojelun Keskusliitto, 61-78.

Peräkylä, Anssi (1990) Kuoleman monet kasvot: identiteettien tuottaminen kuolevan potilaan hoidossa. Tampere: Vastapaino.

Pruett, Marsha Kline \& Insabella, Glendessa M. \& Gustafson, Katherine (2005) The collaborative divorce project: a courtbased intervention for separating parents with young children. Family Court Review 43 (1), 38-51. https://doi. org/10.1111/j.1744-1617.2005.00006.x

Rantanen, Teemu (2007) Huumeiden käytön kehykset sosiaalityöntekijöiden puheessa. Teoksessa Kari Mikko Vesala \& Teemu Rantanen (toim.) Argumentaatio ja tulkinta. Laadullisen asennetutkimuksen lähestymistapa. Helsinki: Gaudeamus, 167-187.

Saini, Michael \& Black, Tara \& Lwin, Kristen \& Marshall, Alena \& Fallon, Barbara \& Goodman, Deborah (2012) Child protection workers' experiences on working with high-conflict separating families. Children and Youth Services Review 34 (7), 1309-1316. https://doi. org/10.1016/j.childyouth.2012.03.005

Sjølie, Hege \& Karlsson, Bengt \& Binder, Per-Einar (2013) Professionals' experiences of the relations between personal history and professional role. Nursing Research and Practice. Epub 2013 Mar 26. https://doi.org/10.1155/2013/265247

Smart, Carol \& Neale, Bren (1999) Family fragments? Cambridge: Polity Press.
Smithson, Janet \& Barlow, Anne \& Hunter, Rosemary \& Ewing, Jan (2015) The 'child's best interests' as an argumentative resource in family mediation sessions. Discourse Studies 17 (5), 609-623. https:// doi.org/10.1177/1461445615590722

Sorokin, Marjaana (2014) Lapsen vieraannuttaminen toisesta vanhemmasta lapsen huolto- ja tapaamisriidassa. Lastensuojelun sosiaalityöntekijöiden näkökulma. Pro gradu -tutkielma. Jyväskylän yliopisto, yhteiskuntatieteiden ja filosofian laitos.

STM: Lapsen arki eron jälkeen - suunnitelma vanhempien yhteistyöstä 2018. https:// stm.fi/documents/1271139/4816712/Va nhemmuussuunnitelma + osa $+3+$ Suunnit elmapohja Luettu 20.6.2019.

Tapola-Haapala, Maria \& Karvinen-Niinikoski, Synnöve \& Kääriäinen, Aino (2012) Parental divorce and children in Finland. Teoksessa Aino Kääriainen, Juha Hämäläinen \& Pirjo Pölkki (toim.) Challenges of divorce, interventions and children. Eron haasteet, väliintulot ja lapset. Helsinki: Ensi- ja turvakotien liitto, 99-123.

Taskinen, Sirpa (2001) Lapsen etu erotilanteissa. Opas sosiaalitoimelle. Oppaita 46. Helsinki: Stakes.

Trinder, Liz \& Kellet, Joanne \& Swift, Louise (2008) The relationship between contact and high conflict cases after divorce or separation. Child and Adolescent Mental Health 13 (4), 181-187. https://doi. org/10.1111/j.1475-3588.2008.00484.x

Vesala, Kari M. \& Rantanen, Teemu (1999) Pelkkä puhe ei riitä. Maanviljelijän yrittäjäidentiteetin rakentumisen sosiaalipsykologisia ehtoja. Helsinki: Gaudeamus.

Vesala, Kari Mikko \& Rantanen, Teemu (toim.) (2007a) Argumentaatio ja tulkinta: Laadullisen asennetutkimuksen lähestymistapa. Helsinki: Gaudeamus.

Vesala, Kari Mikko \& Rantanen, Teemu (2007b) Laadullinen asennetutkimus: lähtökohtia, periaatteita, mahdollisuuksia. Teoksessa Kari Mikko Vesala \& Teemu Rantanen (toim.) Argumentaatio ja tulkinta: Laadullisen asennetutkimuksen lähestymistapa. Helsinki: Gaudeamus, 11-61.

Vuori, Jaana (2001) Äidit, isät ja ammattilaiset. Sukupuoli, toisto ja muunnelmat asiantuntijoiden kirjoituksissa. Tampere: Tampere University Press. 
LIITE 1: HAASTATELTAVILLE ESITETYT VÄITTÄMÄT

1. Mies joutuu avioerossa naista heikompaan asemaan. Sukupuolten tasa-arvo ei toteudu erotilanteessa eikä huoltajuusriidoissa.

2. Erotilanteessa lapset kuuluvat automaattisesti äidille. Isä saa kontolleen elatusmaksut ja tapaamisoikeudet. Lapset riistetään isältä erossa epäoikeudenmukaisin perustein.

3. Naistyöntekijät ja äiti puhuvat samanlaista kieltä, ja siksi he ymmärtävät toisiaan hyvin avioeroon liittyvissä asioissa. Sen sijaan miehet eivät ole kielellisesti yhtä lahjakkaita kuin naiset.
4. Naistyöntekijöiden on helpompi samastua äiteihin, etenkin jos heillä itsellään on kokemusta vanhemmuudesta ja erotilanteesta.

5. Isiä ei nähdä äitien tapaan vastuullisina vanhempina ja arjen pyörittäjinä. Äidin pitää olla todella huono äiti ja isän superisä, jotta ratkaisu lasten huoltajuudesta olisi normaalista poikkeava. 6. Miehet eivät osaa markkinoida itseään hyvinä isinä.

7. Vain miestyöntekijät voivat ymmärtää, miltä miehistä ja isistä tuntuu erossa. 8. Eroasioissa ja huoltajuusriidoissa viranomaiset eivät juuri kuuntele miestä, vaan naista ja äitiä. 